\title{
Agalactosyl IgG, antibodies to heat shock proteins, and acute rheumatic fever
}

G M Bahr, A M Yousof, H A M Majeed, K Behbehani, M Lubani, R B Parekh, R A Dwek, T W Rademacher, D B Young, A Mehlert, J Steele, G A W Rook

\begin{abstract}
In rheumatoid arthritis an increased proportion of the $\mathbf{N}$-linked oligosaccharides on serum IgG terminate with $\boldsymbol{N}$-acetylglucosamine (agalactosyl IgG). It has recently been shown that group A streptococcal cell wall peptidoglycan/polysaccharide complex may be used to raise monoclonal antibodies which bind to this glycoform of IgG.

Patients with rheumatoid arthritis also have increased levels of antibody to the $65 \mathrm{kD}$ and $70 \mathrm{kD}$ families of heat shock proteins, particularly to a bacterial (Mycobacterium bovis) homologue of heat shock protein hsp65. Streptococci must contain similar heat shock proteins.

Acute rheumatic fever follows infection with group A streptococci, and these organisms might theoretically evoke antibody to heat shock proteins or changes in the levels of agalactosyl IgG, which is antigenically cross reactive with their cell walls. It is shown here that serum samples from patients with acute rheumatic fever do not differ from those from normal children by these criteria.
\end{abstract}

Acute rheumatic fever follows infection with group A streptococci. The group A polysaccharide is $N$-acetylglucosamine (GlcNAc) linked B1-3 to polyrhamnose. ${ }^{1}$ Moreover, the group A peptidoglycan is unusually persistent, and after cleavage by lysozyme bears terminal GlcNAc linked $\beta 1-4$ to $n$-acetylmuramic acid. Thus the group A streptococcus is exceptionally rich in terminal GlcNAc, and a powerful antibody response to this sugar is found in patients infected with this organism. ${ }^{2}$

Recent studies of rheumatoid arthritis (RA) have led to renewed interest in the relevance of this property of the group A streptococcus. Firstly, it was shown that patients with RA have increased levels of antibody binding to the peptidoglycan/polysaccharide complex of this organism, though the contribution of antiGlcNAc to this binding was not investigated. ${ }^{3}$ Secondly, the same group showed that when mice were immunised with purified rheumatoid factor they developed increased antibody binding to the streptococcal product. ${ }^{+}$This was attributed to idiotypic complementarity. Alternative explanations are now possible because of the recent discovery of the presence of increased terminal GlcNAc on the IgG of patients with RA. ${ }^{5}$ Briefly, an increased proportion of the IgG from patients with RA lacks terminal galactose from the biantennary oligosaccharides situated on the $\mathrm{CH}_{2}$ domains, ${ }^{5}$ resulting in exposure of increased quantities of terminal GlcNAc. To devise a rapid immunoassay for this agalactosyl form of IgG we required monoclonal antibodies to terminal GlcNAc, and because, as outlined above, the group A streptococcal cell wall is rich in this sugar we chose to immunise the mice with this material. ${ }^{6}$ In this way monoclonal antibodies to the organism responsible for acute rheumatic fever were found to bind to the agalactosyl $\mathrm{N}$-linked oligosaccharides found in an increased proportion on the IgG of patients with RA. ${ }^{6}$ We have been able to use these antistreptococcal antibodies to devise a rapid 'dipstick' assay for agalactosyl IgG.'

A second recent finding in RA sera is the presence of fairly high titres of antibody to the $65 \mathrm{kD}$ heat shock protein of Mycobacterium tuberculosis. Serum samples from patients with $\mathrm{RA}$ contain more antibody to this protein than samples from other autoimmune diseases, or even sera from patients with active tuberculosis. ${ }^{8-10}$ The homology between the mycobacterial $65 \mathrm{kD}$ protein and the human protein is remarkable $(47 \%$ identical residues, and an additional $20 \%$ conservative changes), ${ }^{11}$ and some of this antibody is autoantibody. ${ }^{12}$ The same protein is implicated in the adjuvant arthritis model in rats because $T$ cell clones recognising the mycobacterial $65 \mathrm{kD}$ heat shock protein will transfer the disease to naive irradiated recipients, ${ }^{13}$ and these animals have high agalactosyl IgG (unpublished observations). Thus in RA and adjuvant arthritis, and in several other animal models, there seems to be a circumstantial relation between the presence of antibodies to the $65 \mathrm{kD}$ heat shock protein, and raised levels of agalactosyl IgG. ${ }^{14}{ }^{15}$ As this heat shock protein is a member of a highly conserved family of stress proteins a very similar molecule is present in group A streptococci, which might therefore evoke an immune response to it. ${ }^{16} 17$

The facts outlined above suggested that although RA and acute rheumatic fever are quite different in epidemiology and clinicopathology, at some fundamental level there might be shared pathogenetic pathways. We investigated this possibility by seeking changes in agalactosyl IgG, and changes in antibody to several heat shock protein homologues, in serum samples from patients with acute rheumatic fever. We show here, however, that neither the percentage of $\mathrm{G}(0)$-that is, the percentage of $\mathrm{N}$-linked oligosaccharides on IgG terminating in GlcNAc, nor the titre of antibody to heat shock proteins is significantly raised in acute rheumatic fever, whereas antibody to terminal GlcNAc is strikingly raised as previously reported. ${ }^{2}$

Medicine, School of

Pathology, Riding House

Accepted for publication

11 August 1989 


\section{Patients and methods}

SOURCE OF SERUM SAMPLES

Donors of serum samples used for the immunoassay for agalactosyl IgG, and for antibody studies, were 23 girls and 30 boys aged 5-13 years (mean age 8 years) with acute rheumatic fever attending the paediatric clinic at Mubarak Teaching Hospital in Kuwait. No patients were siblings. A further five serum samples from patients with acute rheumatic fever and five from patients with acute poststreptococcal glomerulonephritis were assayed by the biochemical procedure (tables 1 and 2). The diagnosis was based on the revised Jones criteria. ${ }^{18}$ Serum samples used as controls for the antibody studies were from healthy children from the same environment (18 girls and 21 boys) with a mean age of 9 years (range 6-13). Disease and control sera were from various Arab countries, particularly Kuwait, Jordan, and Saudi Arabia

\section{ANTIGENS USED FOR THE ENZYME LINKED}

IMMUNOSORBENT ASSAY (ELISA)

The recombinant mycobacterial $65 \mathrm{kD}$ heat shock protein ${ }^{16}$ was the preparation to which patients with RA were previously shown to have raised levels of IgG and IgA antibody. ${ }^{8-10} \mathrm{We}$ also used the $65 \mathrm{kD}$ heat shock protein of Escherichia coli, and three antigens belonging to a different heat shock protein gene family. These were the $71 \mathrm{kD}$ heat shock proteins of $M$ tuberculosis, $E$ coli, and human origin.

To measure antibody to terminal GlcNAc the diazonium derivative of $p$-aminophenyl GlcNAc (Sigma) was conjugated onto bovine serum albumin-and used in ELISAs as described previously. 2619

Table 1: Oligosaccharides from the IgG of children with acute rheumatic fever

\begin{tabular}{lcclll}
\hline $\begin{array}{l}\text { Patient } \\
\text { No }\end{array}$ & Age & Sex & $\begin{array}{l}G(0) * \\
(\%)\end{array}$ & $\begin{array}{l}G(1) \dagger \\
(\%)\end{array}$ & $\begin{array}{l}G(2) \neq \\
(\%)\end{array}$ \\
\hline 1 & 9 & M & 25 & 34 & 41 \\
2 & 9 & F & 32 & 36 & 32 \\
3 & 6 & F & 33 & 30 & 38 \\
4 & 10 & F & 28 & 37 & 36 \\
5 & 9 & M & 17 & 32 & 51
\end{tabular}

${ }^{*}$ Arithmetic mean (SD) for $\% \mathrm{G}(0)=27(6) ; \mathrm{G}(0)=$ prevalence of oligosaccharide chains terminating in $N$-acetylglucosamine. tPrevalence of oligosaccharide chains terminating with one galactose residue.

$\ddagger$ Prevalence of oligosaccharide chains terminating with two galactose residues.

Table 2: Oligosaccharide chains from the IgG of children with poststreptococcal glomerulonephritis

\begin{tabular}{lrllll}
\hline $\begin{array}{l}\text { Patient } \\
\text { No }\end{array}$ & Age & Sex & $\begin{array}{l}G(0)^{*} \\
(\%)\end{array}$ & $\begin{array}{l}G(1) t \\
(\%)\end{array}$ & $\begin{array}{l}G(2) \ddagger \\
(\%)\end{array}$ \\
\hline 1 & 6 & M & 21 & 31 & 48 \\
2 & 11 & F & 22 & 35 & 43 \\
3 & 12 & F & 20 & 32 & 48 \\
4 & 6 & M & 19 & 33 & 48 \\
5 & 9 & M & 22 & 39 & 38
\end{tabular}

Arithmetic mean (SD) for \%G(0)=21 (6); $G(0)=$ prevalence of oligosaccharide chains terminating in $N$-acetylglucosamine. †Prevalence of oligosaccharide chains terminating with one galactose residue.

$\ddagger$ Prevalence of oligosaccharide chains terminating with two galactose residues.
ENZYME LINKED IMMUNOSORBENT ASSAY

This assay was as described before. ${ }^{8} 19$

\section{ASSAYS FOR AGALACTOSYL IgG}

Twenty four of the serum samples were tested using a dipstick immunoassay. ${ }^{7}$ To convert the absorbance values yielded by this assay into $\% \mathrm{G}(0)$, standards previously assayed by a biochemical procedure described below were included in each run. The values for these standards were entered into a curve fitting programme (Dataplot, from S M Fraser, department of mechanical engineering, Strathclyde University), which was then used to interpolate the unknowns.

The standard serum samples, which were derived from normal donors and patients with tuberculosis, were assayed as described elsewhere. ${ }^{1}$ Briefly, the $\mathrm{N}$-linked oligosaccharides were released from the IgG by anhydrous hydrazine and purified. The percentage of these oligosaccharides bearing no terminal galactose residues $(G(0))$ was then determined by measuring the hydrodynamic volume after exposure to an exoglycosidase mixture.' A further five serum samples from patients with acute rheumatic fever and five from children with acute poststreptococcal glomerulonephritis were also assayed by this procedure.

\section{Results}

LEVELS OF AGALACTOSYL IgG IN CHILDREN WITH ACUTE RHEUMATIC FEVER

Levels of this glycoform of IgG were normal in acute rheumatic fever sera as determined by the immunoassay. The mean (SD) value for 24 sera was $21.48(10.54) \%$. The five acute rheumatic fever sera assayed by the biochemical procedure gave similar results (table 1), as did those from donors with poststreptococcal glomerulonephritis (table 2). These values are all normal for donors of this age (table 3$).{ }^{20}$ Tables 1 and 2 also indicate the prevalence of oligosaccharide chains with terminal galactose on one or both arms. These are also normal (RBP, RAD, and TWR, unpublished observations). The figure compares these normal results obtained from children with poststreptococcal glomerulonephritis with the grossly abnormal results from children with juvenile $\mathrm{RA}$ in the same age range.

ANTIBODY TO HEAT SHOCK PROTEIN AND TO TERMINAL GICNAC IN ACUTE RHEUMATIC FEVER There were no significant differences between antibody levels in serum samples from patients

Table 3: Prevalence of $G(0)$ oligosaccharides on the $\operatorname{Ig}(\xi$ of healthy subjects

\begin{tabular}{lll}
\hline $\begin{array}{l}\text { Age group } \\
\text { (years) }\end{array}$ & $\begin{array}{l}\text { Mean }(S D) \\
G(0)(\%)\end{array}$ & Sample size \\
\hline $1-5$ & $26(8)$ & 19 \\
$6-10$ & $25(6)$ & 9 \\
$11-15$ & $19(10)$ & 5 \\
$31-35$ & $18(5)$ & 14
\end{tabular}

$\mathbf{G}(0)=$ oligosaccharide chains terminating in $N$-acetylglucosamine. 
Table 4: Antibody levels to heat shock protein antigens in normal children and children with acute rheumatic fever. Values show mean absorbance values $(S D)$

\begin{tabular}{|c|c|c|c|c|}
\hline & \multicolumn{2}{|l|}{ Mycobacterial } & \multirow{2}{*}{$\frac{E \text { coli }}{h s p 70}$} & \multirow{2}{*}{$\frac{\text { Human }}{\text { hsp70 }}$} \\
\hline & $h s p 65^{*}$ & $h s p 70$ & & \\
\hline $\begin{array}{l}\text { IgG } \\
\text { Normal } \\
\text { ARF }^{*}\end{array}$ & $\begin{array}{l}0.345(0.136) \\
0.312(0.146)\end{array}$ & $\begin{array}{l}0.29(0.3) \\
0.28(0.17)\end{array}$ & $\begin{array}{l}0.20(0.21) \\
0.35(0.23)\end{array}$ & $\begin{array}{l}0.33(0.28) \\
0.23(0.19)\end{array}$ \\
\hline $\begin{array}{l}\text { IgA } \\
\text { Normal } \\
\text { ARF }\end{array}$ & $\begin{array}{l}0.131(0.062) \\
0.11(0.056)\end{array}$ & $\begin{array}{l}0.17(0.17) \\
0.16(0.10)\end{array}$ & $\begin{array}{l}0.13(0.09) \\
0.13(0.1)\end{array}$ & $\begin{array}{l}0.21(0.22) \\
0.18(0.24)\end{array}$ \\
\hline $\begin{array}{l}\text { IgM } \\
\text { Normal } \\
\text { ARF }\end{array}$ & $\begin{array}{l}0.326(0 \cdot 162) \\
0.351(0 \cdot 192)\end{array}$ & $\begin{array}{l}0.23(0.15) \\
0.25(0.17)\end{array}$ & $\begin{array}{l}0.35(0.14) \\
0.31(0.1)\end{array}$ & $\begin{array}{l}0.31(0.2) \\
0.25(0.1)\end{array}$ \\
\hline
\end{tabular}

${ }^{*} \mathrm{ARD}=$ acute rheumatic fever; hsp=heat shock protein.

with acute rheumatic fever and those from controls, in any class, to any of the four heat shock protein antigens tested (table 4), though the level of antibody to terminal GlcNAc was raised in acute rheumatic fever $(\mathrm{p}<0.0017)$, as previously reported (table 5$).^{2}$ Individual anti-

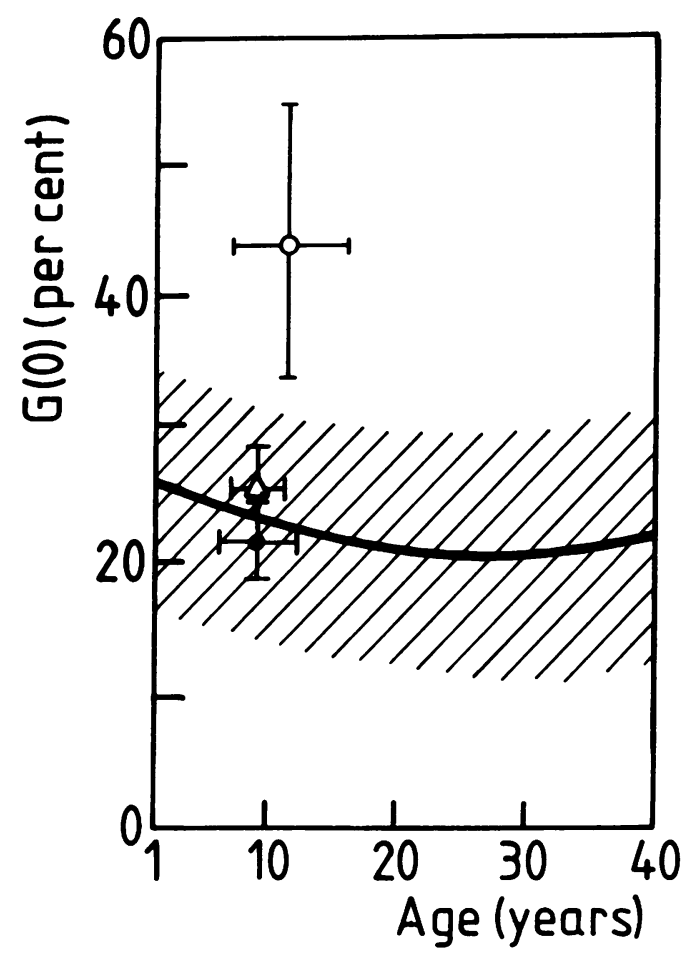

Relation between the prevalence of $G(0)$-that is, the percentage of $N$-linked oligosaccharides on IgG terminating in $N$-acetylglucosamine, and age. The hatched lines indicate 2SD of the normal values of $G(0)$ at different ages. The solid line depicts the mean values. The mean value of $G(0)$ for patients with juvenile arthritis is depicted with an open circle (O). The horizontal and vertical bars represent $2 S D$ for age and prevalence of $G(0)$ respectively. The mean value of $G(0)$ for patients with acute rheumatic fever is depicted by a triangle, and by a solid circle for patients with poststreptococcal glomerulonephritis.

Table 5: Antibody to N-acetylglucosamine (GlcNAc) in serum samples from healthy children and from children with acute rheumatic fever $(A R F)$. Values are given as mean acute
$(S D)$

\begin{tabular}{lll}
\hline & Absorbance & $\begin{array}{l}\text { Mean \% } \\
\text { inhibition by } \\
\text { free GlcNAc } \\
(200 \mu g / m l)\end{array}$ \\
\hline Healthy children $(\mathrm{n}=36)$ & $\begin{array}{ll}0 \cdot 22(0 \cdot 28) \\
\mathrm{p}<0.0017\end{array}$ & $\begin{array}{l}63(15)(\mathrm{n}=12)^{*} \\
\mathrm{NS}(\mathrm{p}=0 \cdot 08)\end{array}$ \\
Children with ARF $(\mathrm{n}=31)$ & $0 \cdot 45(0 \cdot 43)$ & $73(20)(\mathrm{n}=24)^{*}$ \\
\hline
\end{tabular}

${ }^{*}$ Assayed using those sera which gave absorbance values $\geqslant 0 \cdot 2$. body classes were not assayed with this antigen. Binding of the antibody to GlcNAc bovine serum albumin was inhibited by free GlcNAc to a similar degree in patients and controls.

\section{Discussion}

Despite the obvious clinicopathological and epidemiological differences between acute rheumatic fever and RA there are indications, outlined in the introduction, that there might be overlap of the pathogenetic mechanisms in the joint.

We show that there is no rise in the percentage of $\mathrm{G}(0)$, and consequently, of agalactosyl IgG in acute rheumatic fever. This finding is of some importance as the first studies of agalace. tosyl IgG led to the suggestion that it might be fundamental to inflammatory arthritides. Its absence from acute rheumatic fever, however, is in agreement with recent data ${ }^{14}$ suggesting that an increase in this glycoform is an indication of the presence of chronic $T$ cell mediated tissue damage leading to or accompanied by an acute phase response. Thus it rises in RA, Crohn's disease, and tuberculosis ${ }^{21}$ and in leprosy during episodes of erythema nodosum leprosum. ${ }^{7}$ In Crohn's disease it correlates with the serum concentration of $\mathrm{C}$ reactive protein. ${ }^{22}$ It does not rise when there is chronic $\mathrm{T}$ cell mediated inflammation with little rise in $\mathrm{C}$ reactive protein as in sarcoidosis, or in leprosy without erythema nodosum leprosum. ${ }^{21}$ The lack of agalactosyl IgG in acute rheumatic fever also shows that it fails to rise in the reverse situation. Thus in acute rheumatic fever there is acute inflammation and a striking acute phase response but not granulomatous necrotising $\mathrm{T}$ cell mediated tissue damage. Similarly, agalactosyl IgG falls during pregnancy (in preparation) despite the acute phase response which accompanies this state.

We have found no evidence that acute rheumatic fever is associated with raised antibody to antigens of the hsp65 or hsp70 gene families, whereas antibodies to both, particularly the mycobacterial $65 \mathrm{kD}$ gene product, are raised in RA. ${ }^{8-10}$ Confirmation of this point will require further studies using the streptococcal and human hsp65. The latter has recently been cloned, ${ }^{11}$ but to our knowledge the streptococcal gene product is not yet available. Nevertheless, the degree of sequence homology between the heat shock proteins of different organisms is remarkable, ${ }^{11} 1617$ and our results suggest that 
it is unlikely that these gene families constitute major immunogens in acute rheumatic fever.

A further possibility which is not ruled out by this investigation is that terminal GlcNAc, or antibodies to it, may play a part in both these arthritides. Terminal GlcNAc is rare in normal tissues, but it is abundant in rheumatoid joints where it can be detected with the monoclonal antibodies to GlcNAc used to assay agalactosyl IgG. ${ }^{23} 24$ In these joints it is found in a reticular extracellular distribution, indicating deposition in the connective tissue stroma. ${ }^{23}$ It is also seen in a granular pattern within macrophages and on the membranes of a subset of macrophages which is found both in synovial tissue and free in synovial fluid. ${ }^{24}$ The source and nature of this terminal GlcNAc is unknown. It is unfortunate that we do not know if there is similar exposure of GlcNAc in joints during acute rheumatic fever. If there is, it is clearly a possible target for autoimmunity, as we know that some antibodies to group A streptococci will bind to GlcNAc terminating, N-linked oligosaccharides of the mammalian type. ${ }^{6}$ Similarly, we do not yet know whether agalactosyl IgG itself is a target for autoimmunity in RA. Our own antibody binds to it only after the heavy chain has been denatured, and it is unlikely that anti-GlcNAc can behave as rheumatoid factor. We also know that rheumatoid factor levels do not correlate with levels of agalactosyl IgG. The observation that immunisation of mice with rheumatoid factor (likely to include some agalactosyl IgG) led to antibodies binding to streptococcal cell wall products might indicate that agalactosyl IgG can provoke antibody to GlcNAc. ${ }^{4}$

GMB is grateful for support from Kuwait University (grant No MI 042. GAWR and JS are supported by GD Searle, and RBP RAD, TWR, and other members of the Oxford glycobiology unit by the Monsanto Co. DBY and AM are supported by the MRC. We are also grateful to Dr Jan van Embden for supplying the mycobacterial $65 \mathrm{kD}$ heat shock protein.

I Esser R E, Schwab J H, Eisenberg R A. Immunology of peptidoglycan-polysaccharide polymers from the cell walls of group A streptococci. In: Stewart-Tull D E S, Davies M eds. Immunology of the bacterial cell envelope. New York: Wiley, 1985: 91-118.

2 McCarty M. Further studies on the chemical basis for serological specificity of group A streptococcal carbohydrate. 7 Exp Med 1958; 108: 311-28.

3 Johnson P M, Phua K K, Perkins H R, Hart C A, Bucknall R C. Antibody to streptococcal cell wall petidoglycanpolysaccharide polymers in seropositive and seronegative polysaccharide polymers in seropositive and seronegati
rheumatic disease. Clin Exp Immunol 1984; 55: 115-24.
4 Johnson P M, Phua K K, Evans H B. An idiotypic complementarity between rheumatoid factor and antipetidoglycan antibodies. Clin Exp Immunol 1985; 61 : 373-8.

5 Parekh R B, Dwek R A, Sutton B J, et al. Association of rheumatoid arthritis and primary osteoarthrits with Nature 1985; 316: 452-7.

6 Rook G A W, Steele J, Rademacher T. A monoclonal antibody raised by immunising mice with group A streptoantibody raised by immunising mice with group A streptococci binds to agalactosyl IgG from
Ann Rheum Dis 1988; 47: 247-50.

7 Filley E, Andreoli A, Steele J, et al. A transient rise in agalactosyl IgG correlating with free IL-2 receptors during episodes of erythema nodosum leprosum. Clin Exp Immunol 1989; 76: 343-7.

8 Bahr G M, Rook G A W, Al-Saffar M, Van Embden J, Stanford J L, Behbehani K. Antibody levels to mycobacteria in relation to HLA type: evidence for non-HLA-linked high levels of antibody to the $65 \mathrm{kDa}$ heat shock protein of M. tuberculosis in rheumatoid arthritis. Clin Exp Immunol 1988; 74: 211-5.

9 Tsoulfa G, Rook G A W, Van-Embden J D A, et al. Raised serum IgG and IgA antibodies to mycobacterial antigens in serum IgG and IgA antibodies to mycobacterial antigens

10 Tsoulfa G, Rook G A W, Bahr G M, et al. Elevated IgC antibody to the mycobacterial $65 \mathrm{kDa}$ heat shock protein is a characteristic of patients with rheumatoid arthritis. Scand $\mathcal{f}$ Immunol 1989; 30: 519-27.

11 Jindal S, Dudani A K, Singh B, Harley C B, Gupta R S. Primary structure of a human mitochondrial protein homologous to the bacterial and plant chaperonins and to the $65 \mathrm{kDa}$ mycobacterial antigen. Mol Cell Biol 1989; 9 . 2279-83

12 Lydyard P M, Tsoulfa G, Sharif M, et al. Antibodies to heat shock proteins in rheumatoid arthritis. In: Rice-Evans $C$ ed. Stress proteins in inflammation. Richelieu Press, (in press).

13 van Eden W, Thole J E R, van der Zee R, et al. Cloning of the mycobacterial epitope recognised by $T$ lymphocytes in adjuvant arthritis. Nature $1988 ; 331$ : 171-3.

14 Rook G A W. Mycobacteria, the glycosylation of $\mathrm{IgG}$, and rheumatoid arthritis. Scand f Immunol 1988; 28: 487-93.

15 Rook G A W, Stanford J L S, Brealey R, et al. The relationship between immune responses to heat shock proteins, raised levels of agalactosyl IgG and mycobacteria, and their role in rheumatoid arthritis. In: Rice-Evans C, ed. Stress proteins in inflammation. Richelieu Press, (in press).

16 Thole J E R, Keulen W J, de Bruyn J, et al. Characterisation, sequence determination and immunogenicity of a 64 kilodalton protein of Mycobacterium bovis BCG expressed in Escherichia coli K-12. Infect Immun 1987; 55: 1466-75.

17 Young D, Lathigra R, Hendrix R, Sweetser D, Young R A. Young $\mathrm{D}$, Lathigra $\mathrm{R}$, Hendrix R, Sweetser $\mathrm{D}$, Young $\mathrm{R} A$.
Stress proteins are immune targets in leprosy and tubercuStress proteins are immune targets in leprosy and tub

18 Stollerman G H, Markowitz M, Taranta A, Wannamaker L W, Whittemore R. Committee report: Jones criteria (revised) for guidance in the diagnosis of rheumatic fever. Circulation 1965; 32: 664-8.

19 Bahr G M, Rook G A W, Shahin A, Stailford J L, Sattar M I, Behbehani K. HLA-DR-associated isotype-specific regulation of antibody levels of mycobacteria in rheumatoid arthritis. Clin Exp Immunol 1988; 72: 26-31.

20 Parekh R B, Isenberg D A, Roitt I M, Dwek R A Rademacher T W. Age-related galactosylation of N-linked Rademacher T W. Age-related galactosylation of N-linked
oligosaccharides of human serum IgG. 7 Exp Med 1988; 167: 1731-6.

21 Rademacher T W, Parekh R B, Dwek R, et al. The role of IgG glycoforms in the pathogenesis of rheumatoid arthritis. Springer Semin Immunopathol 1988; 10: 231-49.

22 Dube R, Rook G A W, Steele J, et al. Agalactosyl IgG in inflammatory bowel disease: correlation with $\mathrm{C}$-reactive

23 Sharif M, Rook G A W, Wilkinson L S, Worrall J G, Edwards J C W. Terminal $\mathrm{N}$-acetylglucosamine in chronic synovitis. Br 7 Rheumatol 1990; 29: 25-31.

24 Sharif M, Wilkinson L S, Edwards J, Rook G A W. Membrane $\mathrm{N}$-acetylglucosamine; expression by cells in rheumatoid synovial fluid, and by precultured monocytes. Br F Exp Pathol 1989; 70: 567-77. 